\title{
Prison Escape and Defenses Based on Conditions: A Theory of Social Preference
}

Courts have recognized that "the circumstances of prison life are such that at least a colorable, if not credible claim of duress can be raised with respect to virtually every [prison] escape."' Violence, homosexual rape, and extremely unwholesome conditions are so common im prisons that courts have beheved that a defense based on intolerable conditions would be "particularly susceptible to manipulation by . . . shrewd and unscrupulous escapees."

Because many escapees could credibly raise the defense of duress, courts have been reluctant to allow it at all. Thus, the traditional rule is that prison conditions can never justify an escape. ${ }^{3}$ A modern development is to allow a defense based on duress or necessity, but to hedge it with so many limitations devised especially for prison escapees as to make it virtually unavailable. ${ }^{4}$ Because these limitations have hittle realistic reference to prison hfe, they do not measure the culpability of individual defendants, but instead merely reduce the number of escapees who may raise the defense.

Most of the special limitations are simply stricter and more specific versions of the traditional rules of duress. But application of this stricter duress model to prison escape undercuts the social policies on which the duress and necessity defenses are based. The result is that defendants whose escapes seem truly compelled-and who may therefore lack culpability-are convicted, and courts, reluctant to intervene

1. United States v. Bailey, 585 F.2d 1087, 1112 (D.C. Cir. 1978) (Wilkey, J., dissenting).

2. Id. Few prisons approach the minimum standards set by the United Nations and by several American organizations. Comment, The Eighth Amendment and Prison Conditions: Shocking Standards and Good Faith, 44 FordHAM L. Rev. 950, 963 (1976). Government and private reports show that "the right to mimimum standards of decent food, clothing, shelter and medical care, the right to be protected from physical assault while incarcerated, and the right not to be disciplined by torture exist only in theory and rarely can be enforced." Goldfarb \& Singer, $R e$ dressing Prisoners' Grievances, 39 GEO. WASH. L. REv. 175, 187 (1970). The danger of stabbing or homosexual attack, the use of hardened crimmals for guards, and the resultimg fear and unchecked violence are known to prisoners throughout the country. Id. at 189-90; Note, Beyond the Ken of the Courts, 72 YALE L.J. 506, 545 n.186 (1973).

3. See, e.g., Hinkle v. Commonwealth, 109 Ariz. 294, 508 P.2d 1156 (1922) (threats of death or great bodily harm); People v. Whipple, 100 Cal. App. 261, 279 P. 1008 (2d Dist. 1929) ("brutal treatment of extreme atrocity"); Johnson v. State, 122 Ga. 263, 50 S.E. 65 (1905) ("unmerited punishment" by officials); State v. Davis, $14 \mathrm{Nev} .439$ (1880) (grossly inadequate sanitation).

4. See notes 22-27 and accompanying text infra. 
in the administrative domain of prison officials or to appear to condone prison escape, appear instead to condone prison brutality.

A tiberal defense based on conditions cannot solve the problems that plague our prisons. But those problems must be considered in judging the culpability of individual escapees.

This Comment will argue that a new defense, free of the constraints of the duress doctrine, is needed to express the theories of culpability which underhe the defenses of duress and necessity. Part I will examme the conceptual foundation of the doctrines of duress and necessity, the special limitations on those defenses as applied to prison escapees, and the practical effects of those hmitations. Part II will examme the novel "intent" approach espoused by the United States Court of Appeals for the District of Columbia Circuit in the recent case of United States $v$. Bailey. ${ }^{5}$ Part III will propose a new defense of "conditions" which more clearly expresses normative standards of culpability.

An Overview of the Choice-of-Evils Defenses as APPLIED to PRISON ESCAPE

\section{A. Duress and Necessity in General}

In theory, the defense of duress is available when a person commits an offense under immediate threats or conditions which a person of ordinary firmness would be unable to resist. ${ }^{6}$ If, for example, a defendant is ordered at gunpoimt to set fire to a building, he will be excused by duress from criminal liability for arson. The law can serve no deterrent function in such a situation; im any case it is not the function of the law to impose impossible obligations on inen. As Hobbes put it:

No Law can oblige a man to abandon his own preservation. And supposing such a Law were obligatory, yet a man would reason thus, if $I$ doe it not, I die presently; if I doe it, I die afterwards; therefore by doing it, there is time of life gained; Nature therefore compels him to the fact. ${ }^{7}$

In such a situation, moreover, the retributive function of the law is ir-

5. 585 F.2d 1087 (D.C. Cir. 1978).

6. W. LaFave \& A. Scott, Criminal Law 375 (1972) [hereinafter cited as LaFave \& SCOTT].

7. T. Hobbes, Leviathan 157 (Facsimile of 1651 ed. Oxford 1958). The German treatment of prison escape reflects this view-that is, that the law should abstain from imposing impossible obligations. Under German law, the escape itself is not punishable. However, a prisoner who damages property or murders or assaults someone while escaping will be liable for those crimes. R. Maurach, Deutsches Strafecht, Besonderer Teil 654 (5th ed. 1969). This approach is, of course, paradoxical. While it appears to view the urge to be free as a natural quality of humans, it nonetheless imposes incarceration for many offenses and returns escapees to prison once apprehended. 
relevant, since society cannot desire retribution for the failure to fulfill an impossible obligation. Under the traditional view, then, the duress defense is available when, because defendant could not be expected to act other than as he did, he is said to have lacked the voluntariness required for criminal mens rea. ${ }^{8}$

The defense of necessity, on the other hand, is available when a person commits an act which is proscribed by the letter of the law, but which, in the precise circumstances, is the desirable thing to do. Because of immediate circumstances beyond the actor's control, the proscribed act is necessary to avoid a harm or evil which society deems greater than that sought to be prevented by the law defining the offense. ${ }^{9}$ If, for example, the actor sets fire to a building in order to prevent the spread of a brush fire to a neighboring community, the act will be justified by necessity, and no arson will have occurred.

Under the traditional view, the necessity defense is conceptually quite different from the defense of duress. Necessity negates the wrongfulness of the act, rather than the actor's free will. ${ }^{10}$ In the first example above, where the defendant is ordered at gunpoint to set the fire, the crime of arson has occurred, but it is the person holding the gun, not the one holding the match, who is hable. In the second example, no arson has occurred. Society views the event as not only excusable, but also desirable. ${ }^{11}$

The modern view is that both necessity and duress are choice-ofevils defenses which express a social preference that the law be violated if the only alternative is a harn of greater magnitude. ${ }^{12}$ This view recognizes that even in the first example the defendant has made a conscious and reasoned choice to burn the building rather than be shot. And society agrees that damage to property is preferable to serious injury to any person. ${ }^{13}$

Despite the original theoretical differences between the two defenses, courts now use the words duress and necessity almost interchangeably, ${ }^{14}$ merging the two defenses, and apparently accept a choice-of-evils rationale for both defenses. That rationale is implicit in the rule that duress can never justify the taking of human life. ${ }^{15}$ There

8. The defendant would lack the capacity to commit any crime except murder. See notes 66-67 and accompanying text infra.

9. Gardner, The Defense of Necessity and the Right to Escape from Prison, 49 So. CAL. L. Rev. 110, 122-23 (1967).

10. Id. at 123 .

11. See notes 13-15 and accompanying text infra.

12. LAFAVE \& SCOTT, supra note 6 , at 356.

13. Id. at 374.

14. Gardner, supra note 9, at 123.

15. See, e.g., Shannon v. United States, 76 F.2d 490, 493 (10th Cir. 1935). 
could be no such rule if it were actually thought that duress negated the actor's mens rea, and therefore his ability to commit any crime.

One exception to the modern merger of necessity and duress is a continuing distinction with respect to the source-or, more accurately, the form - of the compulsion. For either defense, the threat must be iminediate, and death or great bodily harm unavoidable except by breaking the law. ${ }^{16}$ But for duress, the threat must come from another human being, and must take the form of an order to commit the specific crime that is charged, ${ }^{17}$ while for necessity the threat must arise froin natural physical forces such as fire. ${ }^{18}$

This distinction can mean that neither defense is available to most prison escapees. The defense of duress was unavailable where a prisoner escaped to avoid threatened homosexual rape because there was no specific demand that he commit the crime of escape. ${ }^{19}$ Presumably, a defense of necessity would also have been unavailable since the threat did not arise froin natural physical forces. ${ }^{20}$

\section{B. Special Prerequisites for Escapees}

Some courts have repudiated the "hands off" position of the earlier cases, ${ }^{21}$ without, however, adopting a liberal choice-of-evils defense. Rather, they have imposed special prerequisites that the prison escapee inust meet before he can present a choice-of-evils defense. ${ }^{22}$ The compulsion to escape must have arisen from a specific threat of death or great bodily injury and not from a generalized fear for personal safety. ${ }^{23}$ Also, the threat must have been immediate. If a prisoner escaped several hours before a threat was to be carried out, the defense is unavailable. ${ }^{24}$ Usually, escapees must also show that they requested rehef through administrative channels ${ }^{25}$ or otherwise exhausted alternatives to escape. Courts also require that the escape be accomplislied without violence, ${ }^{26}$ and that the escapee attempt to return

16. LAFAve \& Scotr, supra note 6, at 374,381 .

17. Id. at 379 .

18. Id. at 381 .

19. However, the court conceded that he would have a good defense to the charge of sodomy. People v. Richards, 269 Cal. App. 2d 768, 778, 75 Cal. Rptr. 597, 604 (Ist Dist. 1969). See also State v. Pearson, 15 Utah 2d 353, 354, 393 P.2d 390, 391 (1964).

20. Logically, these rules would render the defense unavailable even to one who cscaped to avoid imminent death. But fortunately, in only two reported opinions have courts applied the rules respecting the form of compulsion to prison escapees. See note 19 supra.

21. See note 3 supra.

22. See Gardner, supra note 9, at 112.

23. Grubb v. State, 533 P.2d 988 (Okla. 1975).

24. State v. Green, 470 S.W.2d 565, 568 n.3 (Mo. 1971).

25. Dempsey v. United States, 283 F.2d 934 (5th Cir. 1960).

26. People v. Lovercamp, 43 Cal. App. 3d 823, 118 Cal. Rptr. 110 (4th Dist. 1974). 
to custody as soon as possible after the threat has been removed. ${ }^{27}$

It has been argued that these restrictions constitute nothing more than a stricter version of the normal rule that the choice-of-evils defenses are available only where a threat reasonably induces fear of imminent and great bodily harm, which leaves no alternative but an illegal course of action. ${ }^{28}$ This stricter version of the general rule is said to be necessary to prevent "a rash of escapes, all justified by unverifiable tales of sexual assault," 29 and to avoid "the judicial sanctioning of escape." 30

In other criminal cases in which a choice-of-evils defense is raised, the defense, unless patently spurious, will generally go to a jury. The jury can then balance such factors as the imminence of the threat against the availability of alternatives, or the seriousness of the harm threatened against that of the crime charged. But in an escape prosecution each of these factors becomes a fixed prerequisite for sending the case to the jury. If any one of them is lacking, the jury will hear no evidence of the circumstances, no matter how harsh, that prompted the escape.

\section{The Context of the Prerequisites}

These rules have evolved without a reahstic assessment of the typical prison or of the individual prisoner's dilemma. A few examples of conditions in specific yet typical prisons suffice to show that the above limitations work to deny the defense to many escapees who might reasonably deem the escape necessary for self-preservation.

The requirement that the threat prompting the defendant's escape be "a specific threat of death, forcible attack, or substantial bodily injury" 31 will often have no bearing on the degree of the defendant's danger. An atınosphere of terror created by unspoken threats, rather than by specific verbal ones, would not excuse an escape. Undeniably, however, such an atmosphere is not uncommon in our prisons. In Holt $v$. Sarver, ${ }^{32}$ for example, the court noted that ineffective security on Arkansas prison farms had led to seventeen stabbings in eighteen months. The court described the problem as follows: "At times deadly feuds arise between particular inmates, and if one of them can catch his en-

27. United States v. Chapman, 455 F.2d 746 (5th Cir. 1972); People v. Lovercamp, 43 Cal. App. 3d 823, 118 Cal. Rptr. 110 (4th Dist. 1974); State v. Reese, 272 N.W.2d 863 (Iowa 1978).

28. United States v. Bailey, 585 F.2d 1087, 1112 (D.C. Cir. 1978) (Wilkey, J., dissenting). See notes 36-40 and accompanying text infra.

29. People v. Noble, 18 Mich. App. 300, 304, 170 N.W.2d 916, 9 I8 (1969).

30. Id.

31. People v. Lovercamp, 43 Cal. App. 3d 823, 831, 118 Cal. Rptr. I10, 114-15 (4th Dist. 1974) (emphasis added).

32. 300 F. Supp. 825 (E.D. Ark. 1969). 
emy asleep it is easy to crawl over and stab him. Inmates who commit such assaults, are known as 'crawlers' and 'creepers,' and other inmates live in fear of them." 33

The court also discussed the problem of homosexual assaults:

An inmate who is physically attractive to other men may be, and frequently is, raped in the barracks by other inmates. No one comes to his assistance; the floor walkers do not interfere; the trusties look on with indifference or satisfaction; the two free world people on duty appear to be helpless. ... . Sexual assaults, fights, and stabbings in the barracks put some inmates in such fear that it is not unusual for them to come to the front of the barracks and cling to the bars all night. ${ }^{34}$

An attractive inmate, or one caught in such a feud, might know, without being told, that an assault was likely. He might not know, however, when or how it would occur. Were he to escape, he would not be allowed to argue that he was in danger. The jury would hear no evidence of the feud or of the likelihood of homosexual assault, because the lack of specificity of the threat would preclude the defense. ${ }^{35}$

That same threat might not be considered sufficiently imminent. In State v. Green, ${ }^{36}$ defendant Green escaped six hours after receiving a threat of "five-fold sodomy" 37 that was not to be carried out until several hours after the escape. The court, in denying the choice-of-evils defense, noted that "this was not a case where defendant escaped while being closely pursued . . .."38 A requirement that a prisoner delay his escape until his assailant has him in hot pursuit is clearly unreasonable, especially if a prisoner knows from prior experience or observation that such threats are likely to be carried out. Moreover, as the Green dissent pointed out, "if escape [is] to save him, it [must] be made earlier than the last minute." 39 A jury might have believed that Green's decision to escape was reasonable, but because the threat was not sufficiently imminent, the jury never heard the evidence that he had been threatened with homosexual assault. ${ }^{40}$

33. Id. at 830 .

34. Holt v. Sarver (II), 309 F. Supp. 362, 377 (E.D. Ark. 1970).

35. See, e.g., Grubb v. State, 533 P.2d 988 (Okla. 1975).

36. 470 S.W.2d 565 (Mo. 1971).

37. Id. at 571 (Seiler, J., dissenting).

38. Id. at 568 .

39. Id. at 570 .

40. In another context, it was recognized that "what constitutes present . . compulsion depends on the facts of each case." People v. Richter, 54 Mich. App. 598, 221 N.W.2d 429 (1974). In that case, it was held that an admission, occurring three weeks after a threat to remove defendant's child and place him in a foster home, would be inadmissible to prove defendant's perjury. The court stated that "a threat occurring three weeks earlier does not make it impossible, as a matter of law, for the compulsion to be present, imminent, and impending." Id. at 602, 221 N.W.2d at $432-33$.

Richter was quoted with approval in People v. Harmon, 394 Mich. 625, 626, 232 N.W.2d 187, 
Green was also denied the defense because he had not requested relief through administrative channels. ${ }^{41} \mathrm{He}$ offered evidence that shortly after entering the prison, he was forced by two other inmates to submit to acts of sodomy "under threat of death or great bodily harm." When he reported the assaults to authorities and asked to be removed from the institution in order to avoid further assault, he was told by the authorities "to resolve his own problems and to 'go back and fight it out." "Following a second hoinosexual assault two weeks later, he feigned an attempt at suicide and asked to be taken to the prison hospital. Instead, he was placed in a disciplinary cell and was taken before the Disciplinary Board the next day. In response to his report of the assaults and request for protection and transfer, a member of the Board told him that he could either "fight it out, submit to the assaults, or go over the fence." "Approximately three months later, Green was told by a group of four or five inmates that he would have to submit to their homosexual desires that evening or they would kill or seriously harm him. He escaped at about six o'clock that evening. ${ }^{42}$

Green did not report the threat which immediately preceded his escape. Yet it was clear in Green that a request for protection would have been futile. The case demonstrates that if the availability of the defense turns on whether such a request was inade, ${ }^{43}$ the defense will be denied and conviction will be inevitable, in many cases where most people would agree that punishment would be unjust.

At least one California appellate court has taken a relatively liberal view, and excused the absence of complaints to authorities where "a history of futile complaints . . . make[s] any result from [them] illusory." "44 However, even this view would not allow the defense in inany cases where justice would seem to dernand it. Prisoners may not report complaints because they reasonably fear serious or even fatal reprisals. ${ }^{45}$

188 (1975), where the fact that defendant delayed his escape for twenty-four hours after a threat of rape was held insufficient to remove a defense of necessity from consideration by the jury.

41. State v. Green, 470 S.W.2d 565, 568 (Mo. 1971), cert. denied, 405 U.S. 1073 (1972).

42. Id. at 566 .

43. A 1968 study of Philadelphia prisons estimated the number of homosexual rapes, among a population of 60,000 inmates, to be 2,000 . Contacting only 3,304 of the inmates, the investigators documented 156 sexual assaults, only 96 of which had been reported. Only 40 of those reported resulted in some disciplinary or protective action. Davis, Sexual Assaults in the Philadelphia Prison System and Sheriff's Vans, 6 Trans-Action 8, 9 (Dec. 1968).

44. People v. Lovercamp, $43 \mathrm{Cal}$. App. 3d at 832, $118 \mathrm{Cal}$. Rptr. at 115.

45. State v. Green, 470 S.W.2d at 569 . Although most, if not all, prisons have established channels for airing grievances, prisoners known to have reported fellow inmates are often subject to serious reprisals. Note, Duress and the Prison Escape: A New Use for an Old Defense, 45 So. CAL. L. REv. 1062, 1074, 1081 n.88 (1973). Prisoners attending a nine-day workshop in Annapolis, Maryland, unanimously disputed the claim that an inmate who reported threats of attack could be protected from retaliation by other inmates. TIME, June 27, 1969, at 78 . 
Failure to complain to authorities should therefore never bar credible defenses based on conditions. If the jury is persuaded that in a particular prison, complamts are both productive and safe, acquittal is unlikely. The jury also may take the defendant's failure to complain into account in assessing his credibility. It may conclude, however, that a reasonable fear of reprisals explains the failure to complain, and that that failure is irrelevant to the question of culpability.

Commission of an assault in the course of escape should similarly not bar evidence of the conditions surrounding the escape under a choice-of-evils rationale. ${ }^{46}$ Those conditions may justify the escape, although not the assault. The crime of escape is not divided into degrees of seriousness, and the commission of an assault does not aggravate an escape. It should simply mean that the escapee is potentially liable for an additional crime. ${ }^{47}$

Even if a defendant fulfills the other prerequisites for a choice-ofevils defense, the requirement of prompt, voluntary return will almost always render the defense unavailable. In many jurisdictions there is a mechanical requirement of return devised especially for prison escapees. ${ }^{48}$ In others, the defense of prison conditions fails because of the general rule of duress that the threat must be imminent. In only three jurisdictions is the defense available despite the defendant's failure to return. ${ }^{49}$ This means that, as a practical matter, the choice-of-evils defense is never available outside those three jurisdictions since it is a rare escapee who, having escaped under conditions amounting to duress, voluntarily returns to custody as soon as he gains safety.

The return requirement has been justified on the rationale that escape is a continuing offense. Although duress may prevent a prisoner from forming a criminal intent at the time of his departure from custody, the offense continues as long as he remains at large. Once the iminediate threat has ceased, the escapee forms the requisite intent and the crime is committed. ${ }^{50}$

46. In fact, the rule that the escape must be accomplished nonviolently appears seldom to be an obstacle. In none of the reported cases in which an escapee raised a defense based on conditions did the escape involve any violence.

47. This is the German view. See note 7 infra.

48. See, e.g., People v. Lovercamp, 43 Cal. App. 3d 823, 118 Cal. Rptr. 110 (4th Dist. 1974); State v. Reese, 272 N.W.2d 863 (Iowa 1978).

49. The jurisdictions are the District of Columbia, lllinois, and Michigan. See, e.g., United States v. Bailey, 585 F.2d 1087 (D.C. Cir. 1978); People v. Unger, 66 lll. 2d 333, 337, 362 N.E.2d 319,324 (1977) ("The Lovercamp preconditions go to the weight and credibility of the defendant's testimony. The absence of one does not alone disprove the claim of necessity."); People v. Harmon, 394 Mich. 625, 232 N.W.2d 187 (1975); People v. Cox, 61 Mich. App. 37, 232 N.W.2d 188 (1975).

50. United States v. Michelson, 559 F.2d 567, 571 (9th Cir. 1977); United States v. Chapman, 455 F.2d 746, 749 (Sth Cir. 1972). 
In practical terms, however, the return requirement is unduly rigid. "[R]equiring the prisoner to turn himself in once he is over the wall, on the possibility that conditions will be different when he is back inside, demands [an unrealistic and unwarranted] measure of faith . . . on his part." 51 It is unrealistic and unjust to expect an escapee, particularly one who fled conditions whicl amounted to duress, to return to those conditions the moment he gains freedom. He can have no reasonable expectation of receiving special protection at his old prison or of transfer to a new, more humane one. In light of this reality, the presence or absence of a return requirement can have no significant effect on the number of escapees who voluntarily return to custody.

Furthermore, elimination of the return requirement would not mean that escapees who were apprehended and brought to trial could forever after "go their merry way" as some courts have feared. ${ }^{52}$ Though acquitted, they would, of course, be returned to prison to serve out their origmal sentences. The absence of a return requirement would simply mean that they might avoid conviction for the additional crime of escape.

It may seem inconsistent to return a prisoner to an institution if a jury has deemed an escape from that institution justified. But the defense should not be denied merely for the sake of logical neatness. If acquittals based on intolerable conditions were to provide incentive to reform the institution, the logical defect would be cured.

Limitations based on the general requirements of the choice-ofevils defenses are logically inappropriate im the context of prison escape. Those general requirements are predicated on the notion that it is preferable, where possible, to remove oneself from the ambit of a threat, rather than violate the law by succumbing to it. The law presumes that only a specific threat of imminent mjury cannot be avoided. But for the prisoner, leaving the ambit of the threat-normally the best means of avoidance-is precisely what the law forbids.

Recent opmions have demonstrated a generalized awareness that prison life is often "harsh, brutal, filthy, unwholesome and inhumane."53 But in imposing special himitations on the duress defense, those courts have overlooked the specific facts of prison life. As a result, the prerequisites limit the number of defendants who may raise the defense at the cost of denying it to many who may lack culpability.

51. State v. Rcese, 272 N.W.2d 863, 868 (Iowa 1979) (McCormick, J., dissenting).

52. United States v. Bailey, 585 F.2d 1087, 1113 (D.C. Cir. 1978) (Wilkey, J., dissenting) (quoting People v. Lovercamp, 43 Cal. App. 3d at 831, 118 Cal. Rptr. at 115).

53. People v. Lovercamp, 43 Cal. App. 3d at 827, 118 Cal. Rptr. at 116. 


\section{The Deterrence Rationale Is Both Unproven and Irrelevant}

In limiting the defense, courts have frequently expressed the fear that otherwise "hordes of prisoners [would leap] over the walls screaming 'rape." "54 But this rationale for denying the defense, or so limiting it that it is virtually unavailable, is unpersuasive. First, it is generally not easy to escape froin prison. A prisoner threatened with rape is more likely deterred by guards and walls than by the thought of an eventual escape conviction. ${ }^{5 s}$ Second, a prisoner who escapes under threats of serious harm is unlikely to be deterred by the thought of a possible escape conviction in the distant future. Third, a liberalized defense would be unlikely to encourage escape since it would by no means assure acquittal. Duress is normally an affirmative defense. Thus, while elimination of special restrictions would help a defendant by allowing him to present evidence of prison conditions, to prevail he would still need to prove each of the elements of the defense by a preponderance of the evidence. ${ }^{56}$

A liberalized defense would mean only that juries could consider evidence of harsh prison conditions in cases where they created a doubt as to an escapee's culpability. The few escape cases in which juries have been allowed to consider exculpatory evidence do not support the fear that juries will render decisions that will encourage escape. ${ }^{57}$ As Judge Wriglit noted in United States $v$. Bailey, "[t]he assumptions underlymg the special restrictions on defense evidence in escape cases appear to be pure speculations without any enpirical support in either the case law or the scholarly literature." 58

An unrestricted defense might well produce no significant increase in acquittals. Such acquittals as occur ought to be welcomed as the expressions of social preference that the choice-of-evils defenses are designed to elicit. Indeed, even in the unlikely event that an increase im acquittals would occur, and would encourage unjustified escapes, a society concerned witl justice should be willing to bear that consequence. Our society should not contmue to deny the defense to escapees who

54. Id. at 831,118 Cal. Rptr. at 115 .

55. In fact, a commonly advanced rationale for the duress defense is that a person who acts under coercion is not subject to deterrence at all. Therefore, invoking the criminal sanction makes little sense. J. Williams, Criminal Law: The General Part 246 (2d ed. 1961).

56. Federal practice, however, shifts the burden of proof to the prosecution, once the defendant has met his burden of coming forward with evidence of the defense. See United States v. Bailey, 585 F.2d 1087, 1120 n.68 (D.C. Cir. 1978) (Wilkey, J., dissenting). Cf. Cal. Penal Code $\S 1093$ (West 1977), construed in People v. McClain, 2 Cal. App. 2d 751, 33 P.2d 710 (2nd Dist. 1934) (burden of proof of justifying or excusing circumstances rests with defendant if facts giving rise to the defense are peculiarly within his knowledge).

57. See, e.g., United States v. Grayson, 550 F.2d 103, 104 (3d Cir. 1976); United States v. Cluck, 542 F.2d 728 (8th Cir. 1976); Syck v. State, 130 Ga. App. 50, 202 S.E.2d 464 (1973).

58. 585 F.2d at 1096 . 
are arguably justified in their actions, on the unproven theory that it will deter unjustified escapes. Our law does not penalize the innocent to deter the guilty.

Finally, the deterrence rationale has not, and will not, lead to penological reform. The limitations on the choice-of-evils defenses are based on a normative ambiguity: while they might provide justice in a world where prisons were what they should be, im the real world, they only work to deny defendants the self-help remedy of escape without encouraging the creation of alternative remedies. If courts were more sympathetic to escape defenses based on intolerable prison conditions, and society did fear-however unreasonably-the spectacle of mass prison escapes, prison reform might actually come about, and the number of escapes could well decrease.

\section{II}

\section{BAILEY AND THE INTENT TO AVOID CONFINEMENT}

The recent case of United States v. Bailey ${ }^{59}$ asserts a principle of judicial responsibility for prison reform and provides a defense that is realistically suited to the prisoner's dilemma. The Court of Appeals for the District of Columbia Circuit imaginatively fashioned a defense based on intent rather than duress. This approach is problematic and perhaps unworkable. Yet it marks a sensitivity to the concept of social preference that underlies the choice-of-evils defenses.

The Bailey court held that harsh prison conditions may negate the intent or voluntariness required for the crime of escape. The court took the followimg steps to reach this conclusion. First, the court repudiated such confusmg and ill-defined terms as "specific" and "general" imtent. ${ }^{60}$ It recognized that an escape simply requires the "intent to avoid confinement." 61 Next, the court differentiated "confinement conditions" from "nonconfinement conditions." "Confinement conditions" are the "normal incidents of confinement" such as strict discipline, poor food, and restrictions on hiberty, privacy, and contact with relatives. "Nonconfinement conditions" include beatings, hoinosexual attacks, and lack of essential medical care. ${ }^{62}$ Finally, the court concluded that if a defendant introduces sufficient evidence of "nonconfinement conditions," the prosecution must prove beyond a reasonable doubt that by his departure from custody the defendant intended to avoid "confinement" as well as "nonconfinement conditions." 63
59. 585 F.2d 1087 (D.C. Cir. 1978).
60. See notes $64-72$ and accompanying text infra.
61. 585 F.2d at 1093.
62. Id. at 1093 n.l7.
63. Id. at 1094. 


\section{A. The Rubric of Intent Is Conceptually Inappropriate}

Criminal intent is a term of art. It normally refers either to the specific intent that is required for the commission of a particular crime, or to voluntariness, the more general predicate of criminal liability. Bailey represents neither of these applications of the rubric of intent. Bailey based its intent analysis on the definition of escape found in United States $v . N i x,{ }^{64}$ but this foundation is weak. In Nix, the sole issue was whether intoxication could negate the intent required for the crime of escape. In the course of its decision, the $\mathrm{Nix}$ court defined the intent eleinent of the crime of escape as the "imtent to avoid confine1nent."65 The Bailey court seized on those words and infused them with a ineaning they did not have in Nix.

Under the traditional approach, the first question would have been whether the crime of escape was one requiring "specific" or "general" intent. A great deal of confusion has been generated by the use of these ill-defined terms, and the distinction drawn between them varies. In the inost cominon usage, "general intent" designates the intent to engage in physical conduct under circumstances that make that conduct criminal. "Specific intent" usually designates a further intent to bring about specified consequences, by engaging in that conduct. ${ }^{66}$ For example, simple assault is a crime of general intent, while assault with intent to kill requires the additional "specific" intent.

The distinction has been crucial in the crimmal law with regard to such defenses as intoxication. The traditional rule is that intoxication can only negate the actor's ability to form specific intent. It cannot negate his general intent to do the prohibited act. ${ }^{67}$ The modern view, however, is that if intoxication blocks formation of the intent required for a particular crime, the crime has not been committed. ${ }^{68}$ This was the view $N i x$ adopted in cutting through the "semantical mishmash"69 of specific versus general intent. Thus, although escape has almost universally been treated as a general intent crime, ${ }^{70}$ the $N i x$ court, defining escape as "a voluntary departure from custody with an intent to avoid confineinent," 71 allowed the defense of intoxication. Nix emphasized

64. 501 F.2d 516 (7th Cir. 1974).

65. Id. at 519.

66. See LAFAvE \& ScotT, supra note 6, at 202.

67. Thus, several courts have held that intoxication, even if it obliterates the intent to have intercourse, can never be a defense to rape because rape is a general intent crime. See, e.g., State v. Scarborough, 55 N.M. 201, 230 P.2d 235 (1951).

68. Model Penal Code $\S 202$, Comment (Tent. Draft No. 4, 1955).

69. 501 F.2d at 520 (Pell, J., dissenting).

70. See, e.g., People v. Dolatowski, 94 Ill. App. 2d 434, 237 N.E.2d 553 (3d Dist. 1968). Cf. United States v. Woodring, 464 F.2d 1248 (10th Cir. 1972) (questionable ruling that specific intent in that particular case had to be proven because indictment charged a "willful" escape).

71. 501 F.2d at 520 . 
the word voluntary: i.e., the defendant must have made a conscious and reasoned decision to leave the prison walls. ${ }^{72}$

The voluntariness required by $N i x$ for an escape conviction was clearly present in Bailey. The Bailey court did not argue that a prisoner's free will or capacity to make decisions may be impaired by "nonconfinement conditions." It did not doubt the voluntariness of appellants' act in escaping; it doubted the wrongfulness of their motive.

In its emphasis on motive, the Bailey intent approach is also unlike a specific intent analysis. For specific intent does not go to motive; rather, it is concerned with the intent to produce a specified consequence or immediate result. Thus, to commit larceny one must not only take and carry away the property of another, but also specifically intend to deprive the owner of it permanently. Even Robin Hood's motive would be irrelevant. ${ }^{73}$ To administer poison with the specific intent to kill is first degree murder. A motive of mercy is irrelevant. ${ }^{74}$ Similarly, the desire to visit one's dying mother or to avoid "non-confinement conditions" is a motive to escape, but the intent in both cases is to exceed permitted limits. In thus rejectimg both voluntariness and specific intent in favor of an approach based on motive, the Bailey decision is at odds with any of the classical definitions of intent that are known to the criminal law. ${ }^{75}$

72. Accord, Gallegos v. People, 159 Colo. 379, 387, 411 P.2d 956, 960 (1966).

73. It makes no difference whether the thief stands to gain any personal benefit. LAFAVE \& ScoTt, supra note 6, at 637.

74. See, e.g., People v. Roberts, 211 Mich. 187, 178 N.W. 690 (1920).

75. The Bailey intent approach is neither a voluntariness nor a specific intent analysis, since the lack of "iutent to avoid confinement conditions" is a lack neither of voluntariness nor of specific intent.

The Bailey court's use of the terms of intent is related, however, to the use of those terms in cases involving entrapment where the concept of voluntariness is often used to express the conclusion that the defendant will not be held responsible for his criminal act because he was "induced" to commit it. See, e.g., United States v. Russell, 411 U.S. 423, 439 (1973) ("It is only when the government's deception actually implants the criminal design in the mind of the defendant that the defense of entrapment comes into play."); Sorells v. United States, 287 U.S. 435, 448 (1932). Yet, it is clear that, no matter how tempting the "inducement" offered by police, the actor does not lack the mens rea required for commission of the crime. If the inducer were not affiliated with the state, there would be no doubt as to the defendant's culpability. The entrapment defense actually expresses the judiciary's reluctance to countenance overzealous law enforcement. See Sherman v. United States, 356 U.S. 369, 381 (1958) (Frankfurter, J., concurring), and the view that "courts must be closed to the trial of a crime instigated by the government's own agents, Sorrells v. United States, 287 U.S. 435, 459 (1932) (Roberts, J., concurring).

Courts which reject the subjective test for entrapment, under which the defense is unavailable to one "predisposed" to commit the crime, see, e.g., United States v. Russell, 411 U.S. 423 (1973), do so on the ground that it "fails to focus on the real concern in these cases-whether actions of the police were so reprehensible . . . that the court should refuse . . . to permit a conviction to stand." People v. Turner, 390 Mich. 7, 13, 210 N.W.2d 336, 343 (1973). See also Greene v. United States, 454 F.2d 783 (9th Cir. 1971); United States v. Bueno, 447 F.2d 903 (5th Cir. 1971).

The notion that the state should be estopped to prosecute crimes for which it is responsible may underlie the Bailey rule that criminal liability should not be predicated on the intent to avoid 
Furthermore, the logical conclusion of the Bailey intent analysis is conviction in every case. This is due to the operation of two well-settled rules. First, one who acted with criminal intent is guilty although he also had some other, noncriminal intent. ${ }^{76}$ Thus, the prosecutor need only prove intent to avoid "confinement" as well as "nonconfinement conditions." Second, an actor "intends" what he knows is substantially certain to follow from his conduct. Since this kind of intent is sufficient for the crime of escape, ${ }^{77}$ it is hard to imagine a defendant whose intent to avoid "confinement conditions" could not be easily established.

The pitfall of dual intent, that is, the inability of noncriminal intent to cure coexisting criminal intent, could be avoided by a jury instruction to base the verdict on dominant intent. Although Bailey is silent on this subject, a thcory of dominant intent would be workable. In all but the most extreine cases of prisoner abuse, the prosecutor could probably persuade the jury to convict based on the defendant's dominant intent to avoid "confinement conditions." But in cases of extremely abusive prison conditions, the jury would not be denied the opportunity to assert the social preferences embodied in the choice-ofevils defenses, and to acquit on the basis of a dominant intent to avoid "nonconfinement conditions."

There are two fundamental objections, however, to a theory of doininant intent. First, it is an unnecessarily roundabout means of permitting the jury to express its preference that a prisoner escape rather than suffer extreme abuse. Second, the concept of dominant intent is

\footnotetext{
"non-confinement conditions." People v. Harmon, 53 Mich. App. 482, 220 N.W.2d 212 (1974), also appears to have favorably considered the notion that the state, which controls both the courts and the prisons, should be estopped to bar a defense based on reprehensible state action. The Michigan Court of Appeal took the view that:

The time has come when we can no longer close our eyes. . . . The persons in charge of our prisons and jails are obliged to take reasonable precautions in order to provide a place of confinement where a prisoner is safe from beatings . . . by fellow inmates, safe from guard ignorance of pleas for help and safe from intentional placement into situations where an assault of one type or another is likely to result. If our prison system fails to live up to its responsibilities in this regard we should not, indirectly, countenance such a failure by precluding the presentation of a defense based on those facts.
}

Id. at 213. Thus, the court, under the theory of duress, allowed a defense limited only by the return requirement and a strict standard of proof.

The Bailey court's use of the terms of intent is consistent with the judicial statements in the entrapment cases that intent may be impaired by reprehensible state action. Just as the entrapment cases use the terms of voluntariness to assert the principle that courts will not countenance "overzealous law enforcement," United States v. Russell, 411 U.S. at 427, Bailey uses the vocabulary of intent to assert a principle of judicial responsibility for penal reform. In both contexts, however, those terms are not only misleading but also conceptually inaccurate.

76. See LA FAvE \& SCOTT, supra note 6, at 204.

77. United States v. Nix, 501 F.2d 516 (7th Cir. 1974). 
unknown to our criminal law, and is inconsistent with the rule that noncriminal intent does not cancel out criminal intent.

Paradoxically, this concept of dual intent would create no problem for the escapee who based his defense on choice of evils rather than intent. If circumstances allow the defense, the fact that the actor has "bad" as well as "good" motives in acting will not destroy it. For example, if A hates B and wishes to kill her, but finally does so in selfdefense, A's malice will be irrelevant. ${ }^{78}$ Similarly, a prisoner who yearns to be free but escapes to avoid death (as, for example, by fire) will not lose an otherwise solid defense of necessity. Thus, a choice-ofevils defense avoids the dual intent pitfall of the Bailey approach.

\section{B. The Concept of Nonconfinement Conditions Is a Means to Express Social Preferences}

Although Bailey's use of intent terminology is eccentric, the decision in fact comports with well-established theories of justification. The Bailey approach stresses a motive justifying an otherwise impermissible act. This notion is also the core of the choice-of-evils doctrines.

Although it is often difficult to draw the line between intent (particularly specific intent) and motive, ${ }^{79}$ avoidance of "nonconfinement conditions" appears to lie squarely in the realm of unotive. When viewed as a theory of motive rather than a theory of intent, the Bailey analysis no longer seems so radical a departure from precedent.

It is often said that motive is immaterial in the criminal law. Yet, choice-of-evils defenses like self-defense and necessity turn on the desirability of the actor's motives. And motive has always been taken into account wherever criminal procedure allows discretion to do so. If a guilty person has a "good" motive, the police may not arrest him, the prosecutor inay not charge him or may reduce the charge, the judge may inpose the ininimum sentence, or the jury may, behind closed doors, acquit him. The effect of Bailey is merely to give escapees access to the jury discretion that other defendants enjoy.

The Bailey intent approach is conceptually similar to the choiceof-evils doctrines. Under Bailey, the jury would decide (1) whether it believes defendant's evidence of harsh prison conditions; (2) whether these conditions are "not normal aspects of confinement;" whether defendant's (primary) $)^{81}$ "intent" in escaping was to avoid such "nonconfinement conditions," rather than to avoid confinement. If the

78. Golden v. State, $25 \mathrm{Ga} .527,532$ (1858).

79. W. Hall, General Principles of Criminal Law 83-93 (2d ed. 1960).

80. United States v. Bailey, 585 F.2d at 1093 n.17.

81. See notes 76-78 and accompanying text supra. 
answer to all three of these questions is in the affirmative, there must be an acquittal.

The key inquiry is the second. It is here that the jury may assert a social preference that the letter of the law be violated by deciding that certain prison conditions are abnorinal and unacceptable "nonconfinement conditions." Under Bailey, as in the normal choice-of-evils case, the jury would assess whether the defendant's motive was blameworthy or desirable in its total factual context. It would not be denied this opportunity simply because one of the fixed prerequisites for a choiceof-evils defense was lacking. The lack of any of the prerequisites would be nuerely a factor bearmg on the defendant's credibility or on the degree of danger in the prison.

The Bailey court accepts the notion of escape as a continuing offense but does not believe that failure to return should foreclose a duress defense as a matter of law. In two respects, however, failure to return would still be relevant. First, the prosecution might attempt to use defendant's failure to return to impeach the credibility of his testiinony about the original danger. ${ }^{82}$ Second, even if it is unquestioned that defendant's original intent was to avoid nonconfinement conditions, he may be convicted of escape if at some point during his absence an "intent to avoid confinement conditions" became dominant. ${ }^{83}$ Again, however, the question of the defendant's intent would be decided by the jury.

The Bailey court's refusal to adopt the timid stance that has been typical of courts faced with evidence of brutal prison conditions is commendable. Motivating the Bailey holding, and implicit in its reasoning, is the belief that society may assert a preference that a prisoner escape rather than suffer inhumane punishment. The rubric of intent, however, is a semantically strained and conceptually unwieldy means of expressing the theories of culpability embodied in the choice-of-evils defenses.

82. By contrast, the defense would argue that the failure to return evidenced the seriousness of the original danger.

83. Such an intent would be difficult to prove. Moreover, the jury's inferences are unpredictable. They might take a dimmer view of the escapee's contentions the longer he had stayed out of prison. Yet, they might be persuaded by his argument that his terror at the moment of departure was so great that it continued to operate on his mind. This debate would tend to return the inquiry to its true focus, that is, the horror of the prison conditions which are claimed to have prompted the escape. Thus even when the charge is based only on failure to return, such failure would not bar credible defenses of duress or necessity, as it would under the normal prerequisites for use of a choice-of-evils defense; see notes 48-52 and accompanying text supra. Rather, the jury would still be free to balance the individual harm from which the prisoner escaped against the general harm to society from the escape and continued liberty of convicted criminals. 
III

\section{A More Coherent Expression of Social Preference}

The choice-of-evils defenses allow society to abstain from invoking the criminal sanction when the facts of a specific situation have rendered comphance with the law either impossible or undesirable. Herbert Packer poimts out that the specialized rules governing use of the various choice-of-evils defenses-necessity, self-defense, defense of others, crime prevention, and the like- - can all be reduced to a single simple prescription: if one who is confronted with a choice of evils makes the 'right' choice, and that choice involves conduct that would violate soine criminal law, he is excused from that violation." 84 Implicit in this "prescription" is the necessity that someone eventually determine the "rightness" of the choice. ${ }^{85}$ Were this determination consistently precluded even im cases where a consensus might well approve the actor's choice, the policies of the choice-of-evils defenses would be undermined.

In the prison escape context, the traditional duress approach does not fulfill the principles of justifiable motive, social preference, and culpability that underlie the choice-of-evils defenses. The Bailey intent approach expresses those principles, but in a conceptually inaccurate inanner. The Bailey court, constrained by classical duress doctrine and by the issues which had been preserved for appeal, strained to achieve a just result. It would be inore coherent, however, to fashion a new common law defense of "conditions" to the crime of escape, a defense tailored to the unique phight of prisoners, and making explicit reference to social preferences.

The opportunity for the defendant to present evidence of intolerable prison conditions and for the jury to weigh its preferences should not be conditioned mechanically on the fulfillment of such criteria as immediacy and specificity of threat, complaint to authorities, and prompt and voluntary return. The first is often irrelevant to the degree of the escapee's danger: yesterday's threat may remam "imminent" until it is carried out, and a vague threat inay be as real as a specific one. Neither is the failure to complain necessarily relevant; in many prisons a complaint inay be of doubtful utility, or dangerous in itself. Finally, the harsher the conditions that prompted a prisoner's escape, the more unrealistic is the deinand that he voluntarily return to custody. In

84. H. Packer, The Limits of the Criminal Sanction 115 (1968).

85. Under the current administration of the duress defense, the court's ruling on the admissibility of the defense is not a true determination of "rightness." The court does not inquire into the totality of the circumstances, but only into fulfillment of the prerequisites. In some instances, of course, as argued in Part I of this Comment, failure to fulfill one or more of the prerequisites has little bearing on the "rightness" of an escape. 
short, all of these criteria may, in specific cases, carry only slight weight in a jury's calculation of its preferences.

Therefore, the defense should be available whenever a jury might reasonably find the escape justified. The jury should be instructed to acquit if it beheves:

(1) that the escapee reasonably believed the escape necessary ${ }^{86}$

(2) to avoid serious physical or psychological harm ${ }^{87}$

(3) due to threats or conditions which would cause a person of reasonable firmness in the defendant's situation to attempt to escape, or which constitute a harm or evil greater than that sought to be prevented by the prohibition on escape. ${ }^{88}$

This instruction does not draw a bright line between the innocent and the guilty. While it would be preferable if it did, such a rule is not possible. The nature of the crime of escape requires the "intertwining inoral and legal judgments" for which juries are best suited. ${ }^{89}$

A crucial reason for constitutional protection of the right to jury trial was that juries could apply the "totality of underlying conceptions of morahty and justice shared by the community, as expressed by its jury surrogate." 90 Under the above instruction, the jury will be called upon to make several judgments that draw upon community standards.

86. The cases are silent on the subject of an escapee's reasonable, but erroneous, belief that he is in danger. It is well settled, however, that one who acts under a reasonable mistake of fact will be judged as if the facts were as he believed them to be. LAFAVE \& SCOTT, supra note 6, at 356. If an escapee claims that he escaped to avoid threatened homosexual rape, the relevant inquiry is not whether he would actually have been raped, but whether a reasonable person in the defendant's position would believe that he would be raped unless he left the prison. The latter question is not only more relevant to the issue of culpability, but also more susceptible of proof.

87. Arguably, incarceration always causes serious psychological harm. But the type of harm that would give rise to the defense is far beyond that which is inherent in confinement. The second clause of the proposed instruction has reference to the third, and thus only that psychological harm which is arguably greater than that sought to be prevented by the prohibition on escape, or from which a person of reasonable firmness would attempt to escape, will give rise to the defense.

It would be arbitrary to limit the defense to situations of physical danger, for this would preclude the defense in many cases where a choice-of-evils inquiry might lead to acquittal. If, for example, a prisoner escaped to avoid unreasonably long solitary confinement, or confinement in a "strip cell," the defense would be precluded as a matter of law unless the psychological harm caused by such confinement had serious physical consequences. Yet, both of these practices have been held to constitute cruel and unusual punishment in violation of the eighth amendment. See cases cited in note 95 infra. And it is possible to imagine other situations in which a prisoner might be faced with the threat of psychological, but not physical, harm arguably serious enough to justify an escape. In other contexts, courts have recognized that the psyche may be gravely injured even if the injury has no physical consequences. See, e.g., State Rubbish Collectors Ass'n v. Siliznoff, 38 Cal. 2d 330, 240 P.2d 282 (1952) (intentional infliction of emotional distress). See also Restatement (SeCOND) OF Torts $\$ 46$ (1965).

88. $C$. Model Penal Code $\$ \S 2.09,3.02$ (Proposed Official Draft 1962).

89. See King v. United States, 372 F.2d 383, 389 (D.C. Cir. 1967).

90. United States v. Brawner, 471 F.2d 969, 982 (D.C. Cir. 1976). See also Williams v. Florida, 399 U.S. 78, 100 (1970). The essential feature of a jury "lies in the interposition between the accused and his accuser of the commonsense judgment of a group of laymen, and in the 
"Serious physical or psychological harm" will, presumably, not be found unless the harm is beyond that which the community, as represented by the jury, deems a necessary, or unnecessary but tolerable, incident of confinement. If the jury finds that the threat to the defendant was "serious," it may judge that threat under the traditional theory of duress, which is represented by the "person of reasonable firmness" test. ${ }^{91}$ Alternatively, the jury may apply the choice-of-evils theory. The jury would first decide what harm the prohibition of escape is designed to prevent. $^{92}$ Next, it would balance the seriousness of that general evil ${ }^{93}$ agamst the individual evil from which the defendant escaped. This comparison mvolves the kmd of value judgment that the choice-of-evils defenses are designed to accommodate, i.e., a decision whether the conditions surrounding the crime were such that society prefers violation of the law to continued endurance of those conditions.

The current prerequisites (imminence of threat, exhaustion of al-

community participation and shared responsibility that results from that group's determination of guilt or innocence."

91. See notes 6-8 and accompanying texts supra.

92. The purpose of escape statutes is less readily apparent than that of most criminal statutes, for most crimes involve injury to person or property. The purpose of escape statutes may be to prevent society from being cheated of its retribution for offenses it has previously chosen to punish. Perhaps a further purpose is to guard against the danger to society that some escapees present, either in the course of escape or because they are not yet fully rehabilitated.

93. It may seem that an individualized inquiry - that is, one focusing on the particular prisoner-is relevant to a choice-of-evils defense. Society, it may be argued, may prefer that a massmurderer suffer even the most brutal treatment, rather than that he escape and subject society to further danger. Such a particularized inquiry, however, is not only inappropriate but also unadministrable.

Under a duress theory, the personality of the actor is clearly irrelevant. However reprehensible his past may be, if duress negates his mens rea he is incapable of committing any crime except murder.

Under the more modern choice-of-evils theory, the assumption that individual personality is relevant is more tempting. But personality is no more germane to the choice-of-evils inquiry in the escape context than it is in other contexts. If A steals food to save his life, no one would suppose that the prosecutor could argue that $A$ was a burden on the welfare system and a habitual criminal, and that these facts should be weighed in the choice-of-evils balance. And if many prisoners fled from a prison which was aflre, no one would argue that those whose original crimes were most serious were "more guilty" of escape than those whose original crimes were petty. Weighing an escapee's past record in the balance would require the assumption that he would repeat his crime. Since this could never be proven beyond a reasonable doubt, the assumptionand the introduction of his past record-would be improper.

Moreover, such an inquiry would not be administrable. For if more abusive conditions are necessary to justify a mass-murderer's escape than that of a petty thief, could a prisoner serving time for an unpaid traffic ticket argue that an insulting remark justifed his escape? It is, of course, unlikely that such an argument would arise. But the example illustrates the administrative difficulty of an individualized inquiry. If such an inquiry were undertaken, both sides would present innumerable and immeasurable details of past record, degree of rehabilitation, and other purely speculative aspects of personality, arguing that these details either raised or lowered the level of brutality a prisoner must suffer before an escape would be justified. Such arguments would divert the inquiry from its true focus - that is, what level of brutality is so inconsistent with common standards of decency as to justify an escape. 
ternatives, avoidance of violence, and voluntary return) may be relevant to this judgment. The absence of one or more of them may lead the jury to convict. But it will not prevent the jury from hearing evidence of harsh prison conditions and delivering a verdict based on knowledge of all the facts which bear on the defendant's credibility.

A minimum threshold of evidence should be required to submit a defense of conditions to a jury. Imprisonment necessarily entails many inherent deprivations, such as curtailment of freedom of movement, boredom, sexual frustration, forced conformity to regulations, and other "confinement conditions." But if an escapee offered evidence of a threat of serious physical or psychological harm-verbal and specific or in any other way demonstrable-the defense would be available.

The duress and choice-of-evils defenses will usually produce the same result. But because they complement and explicate one another, it is useful to offer the jury both. The duress test is simpler, but the choice-of-evils test more accurately describes what ought to be the focus of the jury's mquiry.

When the charge is based on failure to return, the "person of reasonable firmness" standard is clearly an appropriate test of culpability. This is because the fundamental failing of the return requirement is that it inuposes an idealized standard of conduct on escapees, one that is especially unrealistic for those who escaped from conditions of extreme brutality. Thus, the return requirement is inconsistent with the traditional theory of duress that the law should not impose impossible obligations. The jury should therefore be imstructed to judge the reasonableness of defendant's failure to return in light of the totality of the circumstances surrounding his escape.

The proposed imstruction allows acquittal if defendant escaped to avoid serious physical or psychological harm. Extreme filth, severe overcrowdimg," "strip cells" (in which prisoners are held without clothing, bedding, or the means to clean themselves), unreasonably long solitary confinement, and other conditions of extreme unwholesomeness or psychological abuse-all of which have been held to constitute cruel and unusual punishment ${ }^{95}$ - would therefore give rise to the defense, if the judge were persuaded that a reasonable juror could deem the es-

94. A report to the National Commission on Violence noted that hostility in some prisons cannot be contained because prisoners "must fight for space on the fioor to sleep, let alone be accorded the simple comfort of a bed." J. Campbell, J. SABID, \& D. STANG, LaW \& Order RECONSIDERED 579 (1969).

95. See Wright v. McMann, 387 F.2d 519 (2d Cir. 1967) (strip cells lacking heat, light, ventilation, and sanitation); Sostre v. Rochester, 312 F. Supp. 863 (S.D.N.Y. 1970) (13-month solitary confinement); Holt v. Sarver, 300 F. Supp. 825 (E.D. Ark. 1969) (overcrowding); Jordan v. Fitzharris, 257 F. Supp. 674 (N.D. Cal. 1966). 
cape justified. ${ }^{96}$ This is appropriate lest limitations on the jury's opportunity to assess a credible claim of justification be allowed to undercut the fundamental principles of culpability and social preference which legitimate our criminal law.

\section{CONCLUSION}

It has been said that "[j]udges spend their lives in consigning their fellow creatures to prison; and when some whisper reaches them that prisons are horribly cruel and destructive places, and that no creature fit to live should be sent there, they only remark calmly that prisons are not meant to be comfortable."97

96. The proposed choice-of-evils defense would not turn on the existence of an eighth amendment violation. Brutal conditions short of unconstitutionality could give rise to the defense if the balance of social preference tilted in the defendant's favor. For example, if a prisoner could anticipate being homosexually raped exactly once a year, it might not constitute cruel and unusual punishment. This threat might justify an escape, however. Conversely, even a prisoner in an institution which had been held to be constitutionally inadequate would not necessarily have a defense to escape. For if he could not demonstrate that he personally' was affected by the constitutional violation, the defense would be unavailable.

Even if a prisoner were personally affected by abuses of constitutional proportions, such that a judicial remedy might have provided relief, his failure to seek such a remedy should not bar a defense to escape based on the constitutionally inadequate conditions. Undoubtedly, prison life breeds cynicism about the adequacy of legal remedies. Only recently have courts begun to recognize a duty to order alterations in conditions of confinement necessary to eliminate cruel and unusual punishments. See generally Comment, supra note 2; Note, supra note 2. In holding unconstitutional the use of dangerous quantities of tear gas and painful neck chains absent circumstances justifying the use of severe force, and the denial of outdoor exercise for a period of years, one judge observed that

[i]n a significant number of criminal cases . . . [a defendant's] principal concerns are the sentence and conditions of confinement, not a trial to determine guilt or innocence. Yet, by contrast with our determined, even zealous, efforts to shape and refine the adjudication process, courts have given little attention to the elementary requirements of the penal system until recent years.

Spain v. Procunier, 600 F.2d 189, 200 (9th Cir. 1979). The results of eighth amendment challenges appear to be unpredictable, at best. The use of tear gas, for example, has been sanctioned by many courts, see, e.g., Bethea v. Crouse, 417 F.2d 504, 509 (10th Cir. 1969); Landman v. Peyton, 370 F.2d 135, 138 n.2 (4th Cir. 1966), cert. denied, 388 U.S. 920 (1967), but in Spain it was held unconstitutional. An after-the-fact inquiry may lead to the conclusion that an escapee could have received relief under the eighth amendment. But it would be unreasonable to force a prisoner to rely on his own uneducated guess as to whether his particular punishment will shock the conscience of a certain judge, and, if he guesses wrongly and views escape as his only remedy, to penalize him by barring evidence of the unconstitutional punishment at his escape trial.

The eighth amendment has been a powerful tool for prison reform. See, e.g., cases cited in note 95 supra. But the function of the eighth amendment is to regulate our penal system as a whole, and to confer rights on prisoners as a class, while the function of the proposed defense is to avoid unjust convictions in individual cases. In other words, the purpose of a choice-of-evils defense to escape is to allow for the unfortunate facts of prison life when determining individual culpability, while the purpose of the eighth amendment is to correct the worst abuses. Of course, it is hoped that the new defense will encourage prison reform, but the eighth amendment is a more direct route to that end.

97. T. Barnes, 2 Key Issues 11-23 (1965). 
Because of the courts" "hands off" position with respect to prison conditions, the choice-of-evils defenses to escape have solidified into fixed rules which do not express the rationale of those defenses. That rationale, to which the notion of social preference is crucial, can best be expressed through uninhibited jury consideration of credible claims of justification.

United States v. Bailey ${ }^{98}$ revives the principles of social preference that are embodied in the choice-of-evils defenses. It invites the public, as jurors, to scrutinize prison conditions. It does so, however, in the conceptually inaccurate vocabulary of intent.

To decree justice im individual cases, and to coherently express well-accepted theories of culpability, an unrestricted defense of justification is needed. We need not fear a rash of escapes if word of such a defense reaches prison circles. The remote hope of acquittal offered by the new defense would not be an important factor motivating many prisoners-especially those who might credibly raise the defense-to attempt to escape. On the other hand, greater scrutiny of prison conditions, and the publicity which would attend jury trials of the defense, might lead to prison reform. Reform, in turn, might lead to fewer escapes.

A liberal defense to the crime of escape cannot correct all of the failings and abuses of our prison system. But if courts adhere to the inflexible rules of duress, and the "hands off" policy those rules represent, these errors will only be compounded.

Judith Zubrin Gold*

98. 585 F.2d 1087 (D.C. Cir. 1978).

* B.A. 1974, M.A. 1979, Stanford University; third-year student, Boalt Hall School of Law. 